Utah State University

DigitalCommons@USU

1983

\title{
Chemical characteristics of precipitation and hydrogen input in throughfall and stemflow under some eastern Canadian forest stands
}

M.K. Mahendrappa

Follow this and additional works at: https://digitalcommons.usu.edu/aspen_bib

Part of the Forest Sciences Commons

\section{Recommended Citation}

M.K. Mahendrappa. 1983.Chemical characteristics of precipitation and hydrogen input in throughfall and stemflow under some eastern Canadian forest stands. Canadian Journal of forest research. 13 (5):

948-955

This Article is brought to you for free and open access by the Aspen Research at DigitalCommons@USU. It has been accepted for inclusion in Aspen Bibliography by an authorized administrator of DigitalCommons@USU. For more information, please contact

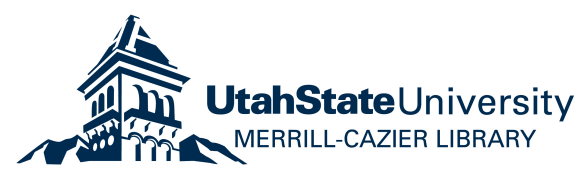




\title{
Chemical characteristics of precipitation and hydrogen input in throughfall and stemflow under some eastern Canadian forest stands
}

\author{
M. K. MAHENDRAPPA \\ Maritimes Forest Research Centre, Canadian Forestry Service, Department of the Environment, P.O. Box 4000, \\ Fredericton, N.B., Canada E3B $5 P 7$ \\ Received December 13, 1982' \\ Accepted May 12, 1983
}

MAHENDRAPPA, M. K. 1983. Chemical characteristics of precipitation and hydrogen input in throughfall and stemflow under some eastern Canadian forest stands. Can. J. For. Res. 13: 948-955.

At the Acadia Forest Experiment Station (AFES) in central New Brunswick chemical characteristics of rain samples collected at five different locations were determined during the 1977-1981 period. Throughfall and stemflow samples from six softwood and three hardwood stands were collected and chemically characterized starting from the early 70's. In 1976 two of four plots in each of the stands were treated with urea at a rate of $225 \mathrm{~kg} \mathrm{~N} \cdot \mathrm{ha}^{-1}$. Both the quantities of rain and their $\mathrm{pH}$ values varied considerably between collections, months, and years. The weighted mean $\mathrm{pH}$ of summer (May-October) rain collected intensively during the 1977-1981 period ranged from 4.5 to 5.1 , with an overall weighted average value of 4.75 for the 5 years. Sulfur and nitrate $N$ measured during May-October 1982 amounted to 6.18 and $1.52 \mathrm{~kg} \cdot \mathrm{ha}^{-1}$, respectively, for the 6-month period. The concentration of hydrogen ion in the throughfall was less than that in the rain. Hardwood throughfall had lower hydrogen levels (higher $\mathrm{pH}$ ) than the softwood throughfall. The $\mathrm{pH}$ of the stemflow from softwoods was lower than that of rain in most cases. Although not significantly, the hydrogen ion concentration of both throughfall and stemflow on the fertilized plots was lower than on the untreated plots. The hydrogen load of rain was reduced by all tree species, but there was considerable variation between species in their abilities to decrease total hydrogen reaching the soil.

MAHENDRAPPA, M. K. 1983. Chemical characteristics of precipitation and hydrogen input in throughfall and stemflow under some eastern Canadian forest stands. Can. J. For. Res. 13: 948-955.

À la station forestière expérimentale de l'Acadie, dans le centre du Nouveau-Brunswick, on a déterminé de 1977 à 1981 les caractéristiques chimiques d'échantillons de pluie recueillis dans cinq stations. À partir du début des années 70 , les précipitations au sol et l'écoulement sur écorce ont été échantillonnés dans six peuplements de résineux et trois de feuillus, puis analysés. En 1976, on a appliqué de l'urée dans deux des quatre placettes de chaque peuplement à raison de $225 \mathrm{~kg}$ azote $\cdot \mathrm{ha}^{-1}$. La quantité et le $\mathrm{pH}$ des précipitations ont varié considérablement d'un prélèvement, d'un mois et d'une année à l'ạutre. La moyenne pondérée du pH des précipitations de mai à octobre, recueillies intensivement de 1977 à 1981 , a varié entre 4,5 et 5,1 , avec une valeur de 4,75 pour les 5 années. L'azote des nitrates et le soufre, dosés de mai à octobre 1982 , se sont chiffrés à 1,52 et à $6,18 \mathrm{~kg} \cdot \mathrm{ha}^{-1}$, respectivement, pour l'ensemble de la période. La concentration des ions hydrogène dans les précipitations au sol a été moindre que dans la pluie. Dans les peuplements de feuillus, elle était plus faible (pH plus élevé) que dans les peuplements de résineux. Dans la plupart des cas, le $\mathrm{pH}$ de l'écoulement sur écorce de résineux a été plus faible que celui des précipitations. La fertilisation des peuplements a eu tendance à abaisser, mais de peu, la concentration des ions hydrogène des précipitations au sol et de l'écoulement sur écorce. Toutes les essences ont réduit l'apport total d'ions hydrogène, mais il y a eu des variations considérables dans la capacité de chacune de réduire la quantité totale d'ions hydrogène qui atteignait le sol.

\section{Introduction}

Eastern Canada is identified as a target area likely to receive a major proportion of the air pollutants originating from the northeastern United States and some industrial areas in Canada. In addition, a few local sources of air pollutants exist in every state or province. Networks of monitoring stations have been established in both Canada (CANSAP/APN) and the United States (MAP3S/RAINE) to characterize the pattern and extent of the distribution of air pollutants. Because of the large area monitored and the high cost of maintaining monitoring stations, these stations are located hundreds of kilometres apart (Anonymous 1982; Barrie and Sirois 1982) and large differences in the data between lo-

\footnotetext{
'Revised manuscript received April 27, 1983.
}

cations and collection dates can be expected. Thus, the data from such large-scale networks are useful for establishing only general trends and cannot be used to generate base-line data for an individual region. A more intensive sampling system may be essential for an accurate evaluation of the quality and quantity of air pollutants deposited in specific regions.

Hydrogen ions associated with the oxides of sulfur and nitrogen, the major constituents of air pollution, are considered to have a greater impact on both aquatic and terrestrial ecosystems than do other air pollutants. For future reference, therefore, it is important to establish a bench mark for the level of hydrogen input in each area. Such information would be useful in detecting gradual changes in the hydrogen input through the years and also in evaluating the deleterious effects of increased 
hydrogen ion input on plant and soil systems. The extent of the impact of acid deposition on terrestrial or aquatic ecosystems depends on the quantities of hydrogen ions generated or neutralized within those ecosystems. Driscoll and Likens (1982) and Nilsson et al. (1982) have demonstrated the importance of including the contributions of weathering and tree growth processes in characterizing the hydrogen cycle and the impact of acid deposition on terrestrial ecosystems.

Reported here are the data on the quantities and concentration of hydrogen ion input in the form of wet plus dry deposition during several summer seasons. Precipitation for the months of May-October was gathered on an event basis at different locations of the Acadia Forest Experiment Station (AFES) during the 19771981 period. Throughfall and stemflow in different forest stands at AFES were collected and chemically characterized during the 1970's. This work constitutes part of the contribution of the Maritimes Forest Research Centre to the Canadian Forestry Service National Project on Long Range Transport of Air Pollutants (LRTAP).

\section{Methods and procedures}

\section{Location}

The work reported here was carried out at the Acadia Forest Experiment Station (AFES), $25 \mathrm{~km}$ northeast of Fredericton in central New Brunswick. The Station is located at longitude $45^{\circ} 59^{\prime} 27^{\prime \prime} \mathrm{N}$ and $66^{\circ} 22^{\prime} 40^{\prime \prime} \mathrm{W}$; the elevation at Station headquarters (location of a CANSAP station) is $60 \mathrm{~m}$ above MSL, while the elevation within the Station, consisting of 10000 ha of forest, ranges from 15 to $175 \mathrm{~m}$ above mean sea level (MSL). The Station is located about $100 \mathrm{~km}$ from the Ste. Annc Nackawic kraft mill in the west, the Coleston Cove oil fired power generating station in the south, and $50 \mathrm{~km}$ from another thermal (coal) power station near Grand Lake in the east. The prevailing wind in this area during the months of May through October is from the southwest. Thus, it is unlikely that these mills or power stations contribute acid to the precipitation at AFES.

\section{Sample collection}

Rainfall collections were taken during the months of May-October at five locations within a radius of about $5 \mathrm{~km}$ from the headquarters of AFES. At each location five Nalgene funnel $(6.1 \mathrm{~cm}$ diameter) collectors and two standard rain gauges $(10 \mathrm{~cm}$ diameter) were installed. Two additional rain measurements (CANSAP station +1 standard rain gauge) were recorded at the headquarters of the AFES.

Collection of throughfall and stemflow had been carried out since 1971, on an event basis, during the months of MayOctober as part of a nutrient cycling study involving three hardwood stands, maple (Acer sp.), white birch (Betula papyrifera Marsh.), and aspen (Populus tremuloides Michx.), and six softwood stands, red spruce (Picea rubens Sarg.), white spruce (Picea glauca (Moench) Voss), red pine (Pinus resinosa Ait.), white pine (Pinus strobus L.), balsam fir (Abies balsamea (L.) Mill.), and larch (Larix laricina
(Du Roi) K. Koch). Three stands, Picea glauca, Pinus strobus, and Pinus resinosa, are plantations, while the others regenerated naturally. In each stand, two of the four circular plots established were treated in 1976 with urea at a ratc of $225 \mathrm{~kg} \mathrm{~N} \cdot \mathrm{ha}^{-1}$. In each plot stemflow collars were installed on 10 random trees four of which represented the average diameter of the trees in the plot. The mensurational characteristics of the stand and the details of the method used for stemflow collection are as follows. Lead collars were nailcd in a spiral around smoothed tree trunks and plastic putty was pasted on the upper edge of the lead collar to prevent leaking. The exposed surface of the lead trough was sprayed with inert plastic. Liquid running down the lead collar was draincd into a plastic bottle through tygon tubing. Stemflow accumulated in the plastic container was collected after each rainstorm (Mahendrappa 1974). Throughfall collection systems used in this study were described in detail in a recent publication (Mahendrappa and Kingston 1982). A brief description is as follows. In each plot, five funnel $(6.1 \mathrm{~cm})$ collectors were installed in a circular pattern. Near the center of the plot a standard rain gauge was also installed for additional measurement of throughfall. Thus for each treatment (two plots) a total of 10 throughfall samples were collected after each rain event for chemical analysis. In addition, a $1-\mathrm{m}^{2}$ plastic collector system was set up in each plot for the collection of 24-L samples used for freeze concentration and freeze drying. Throughfall and stemflow were collected from mid-May through mid-October of each year.

\section{Processing and analyses}

Rain, throughfalI, and stemflow samples were collected after each rain event, filtered through Whatman No. 1 filter paper, and $\mathrm{pH}$ measured the same day. On the few occasions when the $\mathrm{pH}$ measurements were not carried out the same day, the samples were stored overnight at $2^{\circ} \mathrm{C}$. The filtered samples were kept frozen for chemical analysis. Total solids in the samples were determined in $24 \mathrm{~L}$ of filtered liquid by freeze concentration and freeze drying (Mahendrappa and Ogden 1973a).

Most chemical constituents ( $\mathrm{Ca}, \mathrm{Mg}, \mathrm{Na}, \mathrm{K}$, and $\mathrm{Fe}$ ) of the samples were determined with an atomic absorption spectrometer (MacDonald 1977). SuIfate and nitrate N were measured in the 1982 samples. The quantities of sulfate were calculated from $\mathrm{S}$ measurements made with an inductively coupled plasma (ICP) spectrometer (Jobin Yvon JY48P). Nitrate $\mathrm{N}$ was determined using the industrial method No. 100.70 W/B developed by the manufacturer of the Technicon autoanalyzer II. Total nitrogen was determined in the freeze dried materials using a semimicro-Kjeldahl method (MacDonald 1977). Statistical evaluation of all data was carried out using SAS (Helwig and Council 1979).

\section{Rainfall}

\section{Results and discussion}

The observed $\mathrm{pH}$ values of rain collected during the summers from 1977 to 1981 ranged from 3.8 to 7.3 . Of $207 \mathrm{pH}$ measurements, $80 \%$ were greater than $\mathrm{pH} 4.5$ (Fig. 1). Only one set of samples had $\mathrm{pH}$ values less than 4.0. The observed variation in the $\mathrm{pH}$ values for the samples collected from five different locations was 


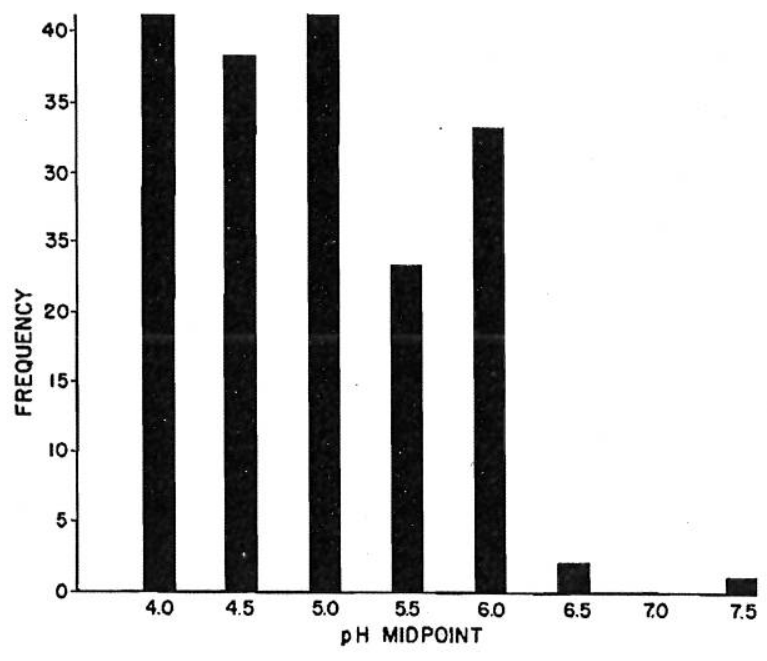

FIG. 1. Frequency distribution of observed $\mathrm{pH}$ values of open-rain samples collected during the 1977-1981 period at AFES.
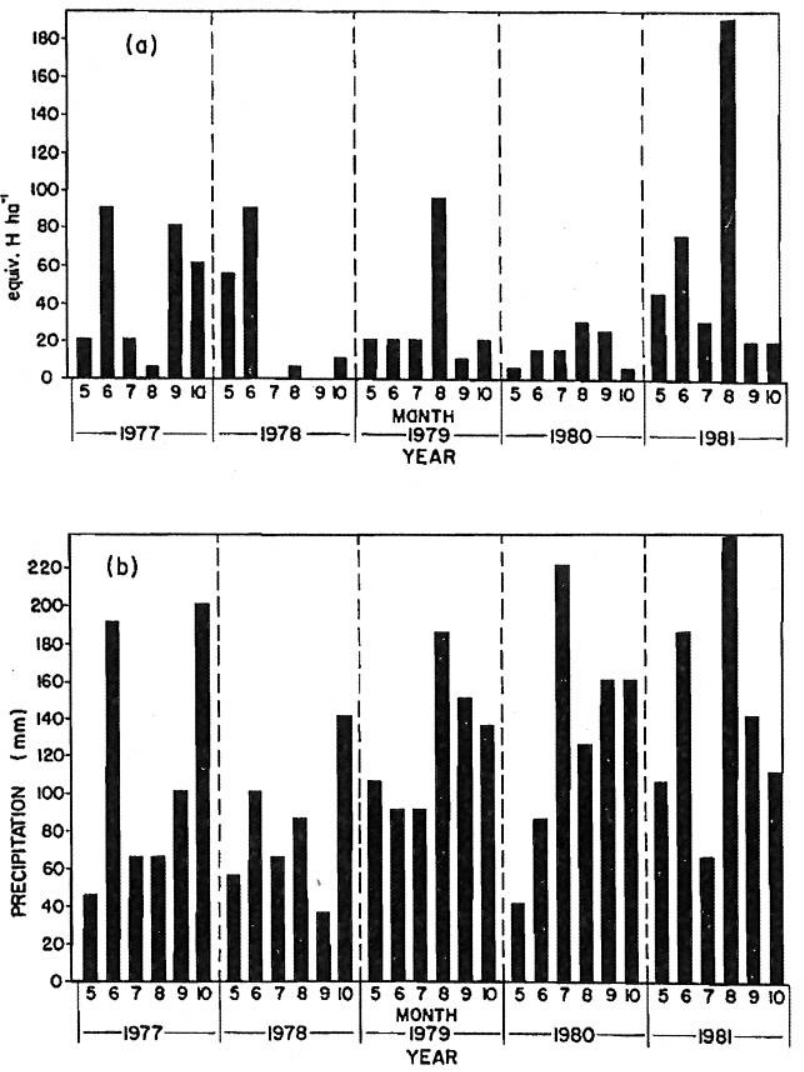

FIG. 2. (a) Weighted mean values for hydrogen input (equivalent $\mathrm{H}$ per hectare) and $(b)$ quantitics (millimetres) of precipitation collected during the 1977-1981 period at various locations at AFES.

less than $10 \%$ of the mean for each rain event. For evaluation of the variation between years, the values of the weighted means for the $\mathrm{pH}$ and the equivalents of hydrogen deposited (per hectare basis) were calculated (Fig. 2). Large differences in the rainfall quantities during different years (Fig. $2 b$ ) were quite evident. The average hydrogen input for corresponding months showed considerable variation between years. No consistent relationships were evident between the weighted mean $\mathrm{pH}$ values for each month, values for hydrogen input per month, and rainfall quantities, contrary to the findings of Raynor and Hayes (1981) for the Long Island area in New York. Large variations in the quantities of hydrogen input between months and between years suggest that for evaluating the impact of acid rain on soils or vegetation, the weighted mean $\mathrm{pH}$ values are no more meaningful than the mean $\mathrm{pH}$ values. The expected impact of a small rain event with high hydrogen ion concentration followed by a high rainfall with low hydrogen ion concentration would certainly be different from that if both rain events contained either high or low hydrogen levels. The interval between rain events would also affect the impact of acidity on either surface soil characteristics or vegetation.

The mean values for various chemical characteristics of rain water collected during the summers of 19771981 are presented in Table 1. The weighted yearly (May-October) mean $\mathrm{pH}$ of rain varied from 4.5 to 5.1 during the 1977-1981 period. The weighted mean $\mathrm{pH}$ value calculated for the entire period of 1977-1981 was 4.75, which is higher than most values reported for the Atlantic region. Among the cations, Na showed the largest variation during this time, with standard deviation (SD) being four times as large as the mean. This is followed by $\mathrm{K}$, which had a SD twice as large as its mean. Average values for the quantity of hydrogen ion input, and the concentrations of $\mathrm{Ca}$ and $\mathrm{Mg}$ showed less variation than $\mathrm{Na}$ or $\mathrm{K}$. These variations further strengthen the argument that the weighted mean values have to be interpreted with extreme caution for evaluating the impacts of acid precipitation on either terrestrial or aquatic ecosystems. These values, however, are quite useful for adjusting the chemical composition of experimental solutions for simulation experiments to study the impacts of acid precipitation on this region. The maximum and minimum values for the chemical characteristics of rainwater collected during 19771981 are useful in setting the ranges for various chemicals to be included in such simulation experiments. Rainfall samples have been periodically collected, for $\mathrm{pH}$ measurements and characterization of chemical constituents, since 1968. The data for the period from 1968-1975 are not continuous enough to permit rigorous evaluation, and thus they are not included in this report. The rain $\mathrm{pH}$ for the 1968-1976 period did, however, show similar values and variations to those reported here.

The concentrations of sulfate and nitrate ions ob- 
TABLE 1. Characteristics of incident precipitation collected at AFES during 1977-1981 (May-October)

\begin{tabular}{lcccccc}
\hline \hline \multicolumn{1}{c}{ Criteria } & $\begin{array}{c}\text { No. of } \\
\text { observations }\end{array}$ & Maximum & Minimum & Mean & SE & SD \\
\hline $\mathrm{N}(\mathrm{ppm})$ & 15 & 1.76 & 0.021 & 0.202 & 0.005 & 0.104 \\
$\mathrm{~K}(\mathrm{ppm})$ & 218 & 9.30 & 0.000 & 0.468 & 0.072 & 1.058 \\
$\mathrm{Ca}(\mathrm{ppm})$ & 216 & 5.00 & 0.000 & 0.560 & 0.036 & 0.528 \\
$\mathrm{Mg}(\mathrm{ppm})$ & 216 & 0.65 & 0.000 & 0.100 & 0.006 & 0.092 \\
$\mathrm{Na}(\mathrm{ppm})$ & 215 & 84.00 & 0.050 & 1.460 & 0.392 & 5.753 \\
$\mathrm{Fe}(\mathrm{ppm})$ & 77 & 0.48 & 0.000 & 0.118 & 0.013 & 0.110 \\
Solids $(\mathrm{ppm})$ & 21 & 43.17 & 4.22 & 15.64 & 2.27 & 10.420 \\
$\mathrm{pH}$ & 207 & 7.30 & 3.800 & $4.75^{*}$ & 0.052 & 0.741 \\
[EH] equivalent & 207 & 41.20 & 0.010 & 7.59 & 0.725 & 9.702 \\
Rain (mm) & 511 & 116.5 & 0.142 & 26.4 & 1.02 & 22.273 \\
\hline
\end{tabular}

*Weighted mean $\mathrm{pH}$.

TABLE 2. Weighted pH values of open rain, throughfall, and stemflow collected during May-October 1977 at AFES

\begin{tabular}{|c|c|c|c|c|c|}
\hline \multirow[b]{3}{*}{ Species } & \multicolumn{5}{|c|}{ Weighted mean pH } \\
\hline & \multirow{2}{*}{$\begin{array}{l}\text { Open } \\
\text { rain }\end{array}$} & \multicolumn{2}{|c|}{ Throughfall } & \multicolumn{2}{|c|}{ Stemflow } \\
\hline & & $+\mathrm{N}$ & $-N$ & $+\mathrm{N}$ & $-\mathrm{N}$ \\
\hline Red spruce & 4.35 & 4.83 & 4.77 & 3.97 & 3.77 \\
\hline White spruce & 4.51 & 4.99 & 4.75 & 4.60 & 4.39 \\
\hline Red pine & 4.42 & 4.73 & 4.87 & 4.61 & 4.09 \\
\hline White pine & 4.21 & 4.94 & 4.96 & 4.47 & 4.39 \\
\hline Balsam fir & 4.51 & 4.64 & 4.82 & 4.33 & 3.93 \\
\hline Larch & 4.51 & 4.67 & 4.53 & - & - \\
\hline Maple & 4.35 & 5.44 & 5.37 & 5.18 & 4.98 \\
\hline Birch & 4.51 & 5.26 & 5.16 & 4.21 & 4.25 \\
\hline Aspen & 4.21 & 5.45 & 5.57 & 6.16 & 6.15 \\
\hline
\end{tabular}

NOTE: $+\mathrm{N}$, from urea-treated plots; $-\mathrm{N}$, control plots.

served in the rain water during the months of MayOctober 1982 also showed considerable variation between rainfall events. Samples of 30 rain events collected from each location at AFES contained sulfate concentrations that ranged from 0.59 to $3.83 \mathrm{ppm} \mathrm{S}$ and nitrate concentrations that ranged from 0.12 to 1.25 $\mathrm{ppm} \mathrm{N}$. For any rain event, $\mathrm{S}$ and $\mathrm{N}$ levels varied little between the five locations at AFES. Although a single season's data may not be considered fully representative, it seems reasonable to suggest that the ratio of sulfate ions to that of nitrate ions is much larger than those reported from the northeastern United States. The observed concentrations of $\mathrm{S}$ and $\mathrm{N}$ represent a net input of $6.18 \mathrm{~kg} \mathrm{~S} \cdot \mathrm{ha}^{-1}$ and $1.52 \mathrm{~kg} \mathrm{~N} \cdot \mathrm{ha}^{-1}$ as nitrate for this area from May-October 1982 with a total precipitation of $629 \mathrm{~mm}$. These values are considerably less than values previously reported for this area of New Brunswick (Cowling 1982; Barrie and Sirois 1982).

\section{Throughfall and stemflow}

Throughfall in softwood stands appeared to have in- variably lower acidity than rainwater while the stemflow was in general richer in hydrogen ion than the rainwater (Table 2). The values of the weighted mean $\mathrm{pH}$ in Table 2 were calculated using the measured throughfall volumes and the $\mathrm{pH}$ of the respective samples. A similar pattern has been reported since 1968 when data were obtained in a black spruce stand (Mahendrappa and Ogden 1973b). The ability of the canopies of different forest tree species to alter the $\mathrm{pH}$ of stemflow and throughfall varied greatly. Hardwood trees generally have a greater capacity to reduce the acidity of rain (as throughfall and stemflow) than do softwoods (Table 2). The $\mathrm{pH}$ of birch stemflow, however, was lower than that of maple and aspen, and similar to that of softwoods.

Fertilizer treatments of forest stands generally improve the nutritional status of the trees and result in increased leaching of cations (Yawney et al. 1978). Such an effect may also be manifested in their ability to reduce the $\mathrm{H}$ content of rain passing through the canopy (throughfall). The data for five out of the nine stands studied suggest an existence of such an effect. In Table 2 the weighted mean $\mathrm{pH}$ values observed in 1977, which are representative of the data for the other years, are presented. In the case of stemflow samples from fertilized softwood plots, the observed $\mathrm{pH}$ values were higher than for the samples from unfertilized plots. Among the hardwoods only the maple stand showed this trend. However, none of the differences owing to fertilizer treatment effect on hydrogen input by either throughfall or stemflow were statistically significant. This could be a reflection of (i) the relatively small number of samples collected, (ii) a gradual decrease in the fertilizer treatment effects since fertilizer application in 1976, and (iii) great variations in the hydrogen input in the rain. It is possible that a hydrogen input and output study in urea-treated and untreated watersheds might have shown fertilizer effects on the ability of 
TABLE 3. Differences between tree species in their ability to alter hydrogen ion concentration of rainwater as throughfall

\begin{tabular}{ccccccccl}
\hline \hline $\begin{array}{c}\text { White } \\
\text { spruce }\end{array}$ & $\begin{array}{c}\text { Red } \\
\text { pine }\end{array}$ & $\begin{array}{c}\text { White } \\
\text { pine }\end{array}$ & $\begin{array}{c}\text { Balsam } \\
\text { fir }\end{array}$ & Larch & Maple & $\begin{array}{c}\text { White } \\
\text { birch }\end{array}$ & Aspen & \\
\hline NS & NS & NS & $* * *$ & $* *$ & NS & NS & $* *$ & Red spruce \\
& $*$ & NS & NS & $* * *$ & NS & NS & NS & White spruce \\
& & NS & $* * *$ & NS & NS & NS & $* * *$ & Red pine \\
& & & $*$ & $*$ & NS & NS & $* *$ & White pine \\
& & & & $* * *$ & NS & NS & NS & Balsam fir \\
& & & & & $*$ & $*$ & $* * *$ & Larch \\
& & & & & & NS & NS & Maple \\
& & & & & & White birch \\
\hline
\end{tabular}

*Significantly different at $\alpha=0.05$.

**Significantly different at $\alpha=0.01$.

$* * *$ Significantly different at $\alpha=0.001$.

TABLE 4. Differences between tree species in their ability to alter hydrogen ion concentration of rainwater as stemflow

\begin{tabular}{|c|c|c|c|c|c|c|c|c|}
\hline White spruce & $* *$ & & & & & & & \\
\hline Red pine & $* *$ & $*$ & & & & & & \\
\hline White pine & $* *$ & NS & NS & & & & & \\
\hline Balsam fir & NS & $* * *$ & NS & $* * *$ & & & & \\
\hline Larch & - & - & - & - & - & & & \\
\hline Maple & **** & $* *$ & $* * *$ & $* * *$ & $* * *$ & & & \\
\hline White birch & $* *$ & NS & NS & NS & $* *$ & - & $* * *$ & \\
\hline \multirow[t]{2}{*}{ Aspen } & $* * *$ & $* * *$ & $* * *$ & $* * *$ & $* * *$ & - & $* * *$ & $* * *$ \\
\hline & Red spruce & White spruce & Red pine & White pine & Balsam fir & Larch & Maple & White birch \\
\hline
\end{tabular}

*Significantly different at $\alpha=0.05$.

**Significantly different at $\alpha=0.01$.

***Significantly different at $\alpha=0.001$.

forest stands to neutralize acid rain.

In view of the potential deleterious effects of acid precipitation, increased leaching of cations from forest canopies is considered by some authors as a negative effect (e.g., Tamm and Cowling 1977). However, the results presented here suggest that with the same levels of acidity, more cations were leached (higher weighted mean $\mathrm{pH}$ of throughfall) from fertilizer-treated plots than from unfertilized plots, and together with the data of Yawney et al. (1978) support a different view to that of Tamm and Cowling (1977). It is possible that greater leaching of cations from tree canopies may mean a faster turnover and better circulation within different components of the ecosystems. This may be particularly true in regard to cations such as $\mathrm{Ca}$ whose mobility is greatly restricted within the trees.

Statistical evaluation of the combined data on hydrogen ion concentration of throughfall for the 1976-1981 period showed that significant differences exist among some hardwoods and softwoods in their ability to reduce the acidity of rainwater (Table 3 ). There were no significant differences between spruces and pines, but they both differed significantly from balsam fir and larch. Maple did not show any difference from the spruces and pines. It should be pointed out that analyses of similar data for each year showed variations between more species than seen in Table 3 . Levels of significance of differences on an individual year basis can be expected to vary owing to the variations in the rainfall effects on water economy, nutrient status, and tree growth (Mahendrappa 1982).

Evaluation of the combined (1976-1981) data on the ability of trees to alter hydrogen ion concentration in stemflow (Table 4) also showed differences between species. Although the hardwoods as a rule were better able to neutralize acid rain than were softwoods, both the hardwoods and some softwoods significantly differed from one another in their ability to neutralize acidity in the rain, as stemflow. While the pH's of throughfall under red spruce and white spruce were not statistically different, the stemflow $\mathrm{pH}$ for these two softwoods were significantly different from each other. Similarly the stemflow $\mathrm{pH}$ of birch was significantly different from that of maple and aspen. The frequency distribution of the $\mathrm{pH}$ values, of stemflow and throughfall, observed during the summers of 1976-1981 are presented in Fig. 3. Although most of the histograms are skewed to the left (acidic side) there are species with relatively high $\mathrm{pH}$ for both stemflow and throughfall. In general, the throughfall $\mathrm{pH}$ was higher than that of 

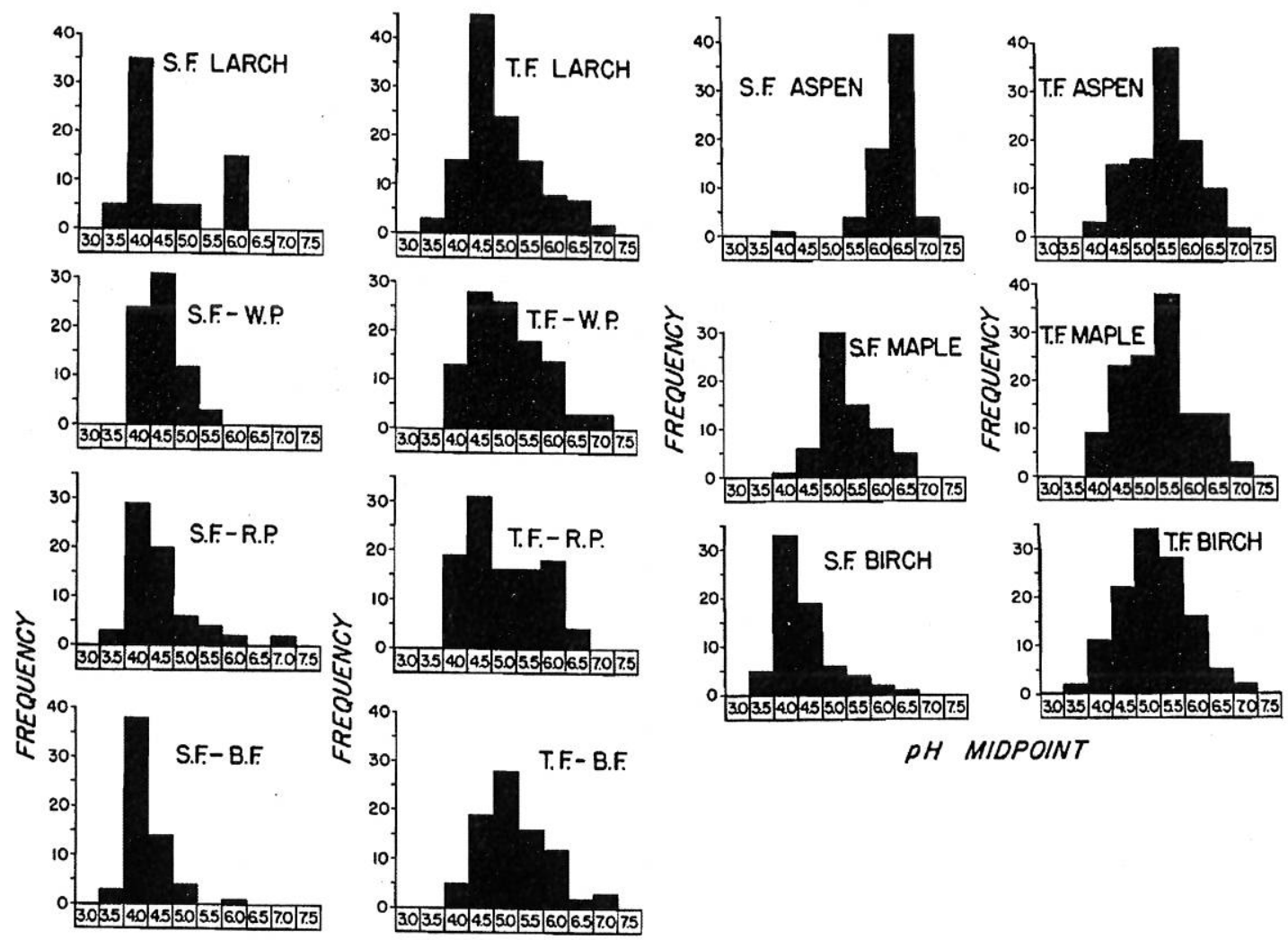

PH MIDPOINT
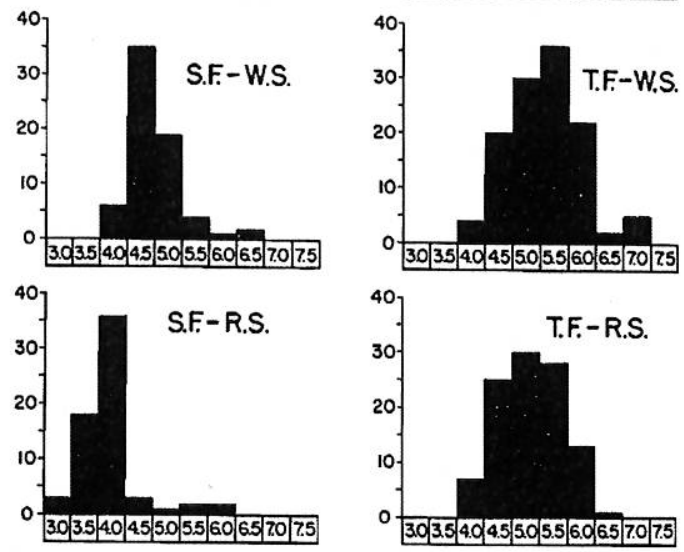

PH MIDPOINT

FIG. 3. Frequency distribution of $\mathrm{pH}$ values of throughfall and stemflow samples collected during the 1976-1981 period, from different stands at AFES.

stemflow. A general difference between the $\mathrm{pH}$ of hardwood and softwood throughfall and stemflow can be seen in the histograms.

To be able to predict the quantities of throughfall liquid reaching the ground under the stands of different species being studied at AFES, rainfall and throughfall quantities were measured very intensively during 1977 and 1978 and mathematical models were developed (Mahendrappa and Kingston 1982). Using these models and rainfall measured during May-October, throughfall quantities for each species were calculated. Simi- larly, the stemflow quantities were calculated from rain measurements using the relationships between stemflow and rainfall quantities established earlier (Mahendrappa 1974). The total hydrogen ion input (equivalent $\mathrm{H}$ ) during the summer (May-October) months, in the form of stemflow and throughfall under different stands was then calculated using the above information on rainfall quantities and the hydrogen ion concentration data from $\mathrm{pH}$ values of stemflow and throughfall samples from individual rain events. Values in Table 5 represent the average quantities of hydrogen 
TABLE 5. Average quantities of hydrogen (equivalents per hectare) deposited on the forest floor by stemflow and throughfall compared with that by rain, during the summer (May-October) months of 1977-1981

\begin{tabular}{lrrrrr}
\hline \hline \multirow{2}{*}{ Species } & \multicolumn{4}{c}{ Hydrogen ion input (equiv. ha ${ }^{-1}$ ) } & \\
\cline { 2 - 5 } & \multicolumn{1}{c}{ SF } & \multicolumn{1}{c}{ TF } & SF + TF & Rain & $\begin{array}{c}\text { Percent } H \\
\text { neutralized }\end{array}$ \\
\hline Red spruce & 23.03 & 103.16 & 126.19 & 235.41 & 46 \\
White spruce & 9.07 & 52.78 & 61.85 & 189.54 & 67 \\
Red pine & 5.19 & 113.36 & 118.55 & 208.65 & 43 \\
White pine & 13.24 & 105.03 & 118.27 & 224.08 & 47 \\
Balsam fir & 16.03 & 72.26 & 88.29 & 189.50 & 53 \\
Larch & 6.83 & 142.03 & 148.86 & 189.54 & 21 \\
Maple & 2.39 & 64.14 & 66.53 & 219.81 & 69 \\
Birch & 14.77 & 98.94 & 113.71 & 189.54 & 40 \\
Aspen & 0.44 & 43.37 & 43.81 & 224.08 & 80 \\
\hline
\end{tabular}

ion input for the summer (May-October) months during the 1976-1981 period. Hydrogen ion input during the early parts of May and latter part of October, when throughfall and stemflow samples were not collected, was estimated by using the average values for the weighted hydrogen ion input during the respective months. Also included in Table 5 are the differences between the quantities of hydrogen input by rain and those deposited by the stemflow plus throughfall liquid. These values are useful in evaluating the relative ability of different species to modify hydrogen concentration of rain during its passage to the forest floor over a considerable time frame.

Hydrogen ion input by both throughfall and stemflow varied considerably from one event to another. This in general was a reflection of the variations observed in the quantities of hydrogen input by rain and the nutritional status of the trees. Hydrogen ion input by stemflow was small, owing to its small volume compared with the much larger volumes of throughfall or rain. Hydrogen input by the hardwood stemflow (maple and aspen) was smaller than that by the softwood stemflow in spite of larger stemflow volumes for the hardwoods. There were significant differences in hydrogen input by stemflow between the softwoods.

Differences between species with respect to the quantities of hydrogen input by stemflow suggest $(i)$ the possible impact of acid precipitation on soil chemical properties around the trees will be dependent on the tree species, and (ii) the existence of a gradient in soil chemical characteristics with respect to both the distance from the tree trunk along the roots and depth of soil from the surface. The thickness of the Ae horizon in podzolic soils, an indicator of the extent of leaching, is generally considered to be greater under and around tree trunks than at some distance from the trunks. Gersper and Holowaychuk $(1970 a, 1970 b)$ have presented evidence to suggest that stemflow alters soil chemical characteristics. Thus in the areas with high acid precipitation investigation of soils around the trees may demonstrate the potential deleterious effects of acid precipitation on trees. Stemflow with high acidity may increase the solubility of toxic heavy metals such as $\mathrm{Cu}, \mathrm{Al}, \mathrm{Mn}$, etc., in the immediate vicinity of the root zone causing the death of fine roots as found by Ulrich et al. (1980) in the Solling region of Germany. Loss of fine roots and damage to plant-microbial associations can therefore be expected without any major change in the levels of toxic metals being detected in soils sampled away from the tree trunks.

Parallel to the observed differences between species with respect to the concentrations of hydrogen ion in throughfall samples (Table 2), the total quantities (equivalents) of $\mathrm{H}$ per hectare reaching the ground during the summer (May-October) months under different species as throughfall also show significant differences (Table 5). The lower proportion of rain reaching the ground as throughfall under softwoods as compared with hardwoods (Mahendrappa and Kingston 1982) apparently was not large enough to counterbalance the differences in the levels of acidity between hardwoods and softwoods. Softwood stands intercepted a higher proportion of rain, by returning moisture to the atmosphere through the evapotranspiration processes, than the hardwood stands studied at AFES (Mahendrappa and Kingston 1982). Yet the softwoods contributed more hydrogen ions (as shown by lower percentage of $\mathrm{H}$ in the rain neutralized) than the hardwoods to the soils under the stands. However, owing to their ability to neutralize hydrogen in rain water, both the hardwoods and softwoods appeared to reduce the overall hydrogen input to the soil. These results suggest that in evaluating hydrogen budgets for watersheds as reported by Driscoll and Likens (1982) and in considering tree growth as a hydrogen generator in the ecosystems (Nilsson et al. 1982) the contributions of stemflow and 
throughfall in neutralizing hydrogen in precipitation should be taken into account, along with species effects and inherent fertility levels of different forest sites.

\section{Acknowledgments}

The author is grateful to Kathy Beaton and Dermot Kingston for carrying out the statistical analyses of the data.

ANONYMOUS. 1982. MAP3S/RAINE precipitation chemistry network: statistical overview for the period 1976-1980. Atmos. Environ. 16: 1603-1631.

BARRIE, L. A., and A. SiroIs. 1982. An analysis and assessment of precipitation chemistry measurements made by CANSAP (The Canadian Network for Sampling Precipitation) 1977-1980. Environ. Can. Rep. No. ARRB-82-003-T.

Cowling, E. B. 1982. Acid precipitation in historical perspective. Environ. Sci. Technol. 16: 110A-122A.

Driscoll, C. T., and G. E. LiKENS. 1982. Hydrogen ion budget of an aggrading forested ecosystem. Tellus, 34: 283-292.

Gersper, P. L., and N. Holowaychuk. 1970a. Effects of stemflow water on a Miami soil under a beech tree. I. Morphological and physical properties. Soil Sci. Soc. Am. Proc. 34: 779-786.

$1970 b$. Effects of stemflow water on a Miami soil under a beech tree. Il. Chemical properties. Soil Sci. Soc. Am. Proc. 34: 786-794.

HelwiG, J. T., and K. A. CounC1L (Editors). 1979. SAS user's guide. SAS Institute Inc., Raleigh, NC.

MACDONALD, C. C. 1977. Methods of soil and tissue analysis used in the analytical laboratory. Can. For Serv. Marit. For. Res. Cent. Inf. Rep. No. M-X-78.

MAHENDRAPPA, M. K. 1974. Chemical composition of stem- flow from some eastern Canadian tree species. Can. J. For. Res. 4: $1-7$.

1982. Effects of forest cover type and organic horizons on potential water yield. I $n$ Hydrological processes of forested areas. Proceedings of the Canadian Hydrology Symposium. 13-15 Junc 1982, Fredericton, N.B. pp. 215-224.

MahendRappa, M. K., and D. G. O. Kingston. 1982. Prediction of throughfall quantitics under different forest stands. Can. J. For. Res. 12: 474-481.

Mahendrappa, M. K., and E. D. Ogden. 1973a. Freeze concentration of Burpee Millstream water and its chemical composition. Can. For. Serv. Marit. For. Res. Cent. Inf. Rep. No. M-X-36.

$1973 \mathrm{~b}$. Effects of fertilization of a black spruce stand on nitrogen contents of stemflow, throughfall and litter fall. Can. J. For. Res. 3: 54-60.

Nilsson, S. I., H. G. Miller, and J. D. Miller. 1982. Forest growth as a possible cause of soil and water acidification: an examination of the concepts. Oikos, 39: 40-49.

RAYNOR, G. S., and J. V. HAYES. 1981. Acidity and conductivity of precipitation on central Long lsland, New York in relation to meteorological variables. Water Air Soil Pollut. 15: $229-245$.

TAMM, C. O., and E. B. Cowling. 1977. Acidic precipitation and forest vegetation. Water Air Soil Pollut. 7: 503-511.

Ulrich, B., R. MAYeR, and P. K. Khanna. 1980. Chemical changes due to acid precipitation in a loss-derived soil in central Europe. Soil Sci. 130: 193-199.

YAWNEY, H. W., A. L. Leaf, and R. E. LeOnaRd. 1978. Nutrient content of throughfall and stemflow in fertilizer and irrigated Pinus resinosa (Ait) stands. Plant Soil, 50: 433-445. 